\title{
IMPLEMENTASI MANAJEMEN BERBASIS SEKOLAH UNTUK MENINGKATKAN MUTU PENDIDIKAN DI SMP NEGERI 17 PURWOREJO
}

\author{
Muhamad Churdaini
}

(SMK Maarif NU 1 Bener Purworejo) churdaini@gmail.com

\begin{abstract}
ABSTRAK
Penelitian ini didasari oleh pentingnya manajemen berbasis sekolah. Sehubungan dengan hal tersebut, penelitian ini bertujuan untuk mengetahui Impelentasi Manajemen Berbasis Sekolah untuk Meningkatkan Mutu Pendidikan di SMP Negeri 17 Purworejo. Penelitian ini merupakan penelitian kualitatif. Pengumpulan data menggunakan wawancara, observasi, dan dokumentasi, dan keabsahan data menggunakan triangulasi, dan teknik analisis data meliputi pegumpulan data, reduksi data, penyajian data, dan penarikan kesimpulan. Penelitian ini menghasilkan empat kesimpulan: (1) Otonomi sekolah dalam meningkatkan mutu pendidikan di SMP N 17 Purworejo sudah berjalan sesuai dengan ketentuan peraturan yang berlaku. (2) Partisipasi sekolah dalam meningkatkan mutu pendidikan di SMP N 17 Purworejo yaitu dengan melibatkan seluruh stakeholder sekolah terkait. Partisipasi dilakukan dalam kegiatan perencanaan, penetapan kebijakan, maupun dalam penyelenggaraan pendidikan di sekolah. (3) Kepemimpinan kepala sekolah dalam meningkatkan mutu pendidikan di SMP N 17 Purworejo berjalan dengan baik. Kepala sekolah mampu melaksanakan perannya sebagai leader dan manajer secara seimbang. (4) Kerja tim sekolah dalam meningkatkan mutu pendidikandi SMP N 17 Purworejo yaitu dilakukan dengan kekompakan dan kebersamaan yang kuat, sehingga mampu mengatasi persoalan secara optimal.
\end{abstract}

Kata kunci: Manajemen Berbasis Sekolah, Mutu Pendidikan.

\section{PENDAHULUAN}

Salah satu aspek yang berfungsi dan berperan dalam menyiapkan sumber daya manusia (SDM) yang berkualitas adalah pendidikan. Dengan kata lain, pendidikan memiliki peran strategis untuk menciptakan SDM yang berkualitas. Namun demikian, pendidikan di Indonesia belum sepenuhnya dapat memenuhi harapan masyarakat. Salah satu permasalahannya adalah rendahnya kualitas proses dan hasil pendidikan pada setiap jenjang dan satuan pendidikan yang ada. Berbagai upaya telah dilakukan pemerintah untuk meningkatkan mutu pendidikan nasional. Salah satunya adalah dengan penerapan Manajemen Berbasis Sekolah (MBS) yang dalam praktiknya lebih dikenal sebagai Manajemen Peningkatan Mutu Berbasis Sekolah (MPMBS). Secara umum, MPMBS diartikan sebagai model manajemen yang memberi otonomi yang lebih besar kepada sekolah dan mendorong pengambilan keputusan partisipatif yang melibatkan secara 
langsung semua warga sekolah untuk meningkatkan mutu sekolah berdasarkan kebijakan pendidikan nasional. ${ }^{38}$

Secara konseptual MBS atau MPMBS dipahami sebagai salah satu alternatif pilihan formal untuk mengelola struktur penyelenggaraan pendidikan yang terdesentralisasi dengan menempatkan sekolah sebagai unit utama peningkatan. Konsep ini menempatkan redistribusi kewenangan para pembuat kebijakan sebagai elemen paling mendasar, untuk meningkatkan kualitas hasil pendidikan. Pada sisi ini MBS merupakan cara untuk memotivasi kepala sekolah untuk lebih bertanggung jawab terhadap kualitas peserta didik. Untuk itu sudah seharusnya kepala sekolah mengembangkan program-program kependidikan secara menyeluruh untuk melayani segala kebutuhan peserta didik di sekolah. ${ }^{39}$ Lebih lanjut dikemukakan, semua personel sekolah harus berperan serta merumuskan program yang lebih operasional, karena merekalah pihak yang paling mengetahui akan kebutuhan peserta didiknya.

Di Indonesia, pendekatan MBS di samping diposisikan sebagai alternatif, juga sebagai kritik atas penyelenggaraan pendidikan yang selama ini tersentralisasi. Pendidikan sentralistis tidak mendidik manejemen sekolah untuk belajar mandiri, baik dalam hal manajemen kepemimpinan maupun dalam pengembangan institusional, pengembangan kurikulum, penyediaan sumber belajar, alokasi sumber daya dan terutama membangun partisipasi masyarakat untuk memiliki sekolah. Peningkatan pengaruh sekolah, perlu dukungan para stakeholder yang meliputi pemerintah daerah, komite sekolah (kepala sekolah, guru, orang tua siswa, dan tokoh masyarakat), serta siswa. Pengambilan putusan bersama di kalangan stakeholder pada level sekolah merupakan kunci utama dalam melaksanakan MBS..$^{40}$

Kekuatan manajemen pendidikan diarahkan untuk lebih memberdayakan sekolah sebagai unit pelaksanaan terdepan dalam kegiatan belajar mengajar di sekolah. Hal ini dimaksudkan agar sekolah lebih mandiri dan bersikap kreatif, dapat mengembangkan iklim kompetitif antarsekolah di wilayahnya, serta bertanggung jawab terhadap stakeholders pendidikan, khususnya orang tua dan masyarakat yang di era otonomi ini akan menjadi dewan sekolah. Dalam pelaksanaannya, manajemen pendidikan harus lebih terbuka, accountable, mengoptimalkan partisipasi orang tua dan masyarakat, serta dapat mengelola semua sumber daya yang tersedia di sekolah dan lingkungannya untuk

\footnotetext{
${ }^{38}$ Nurkolis. Manajemen Berbasis Sekolah: Teori, Model, dan Aplikasi. (Jakarta: Grasindo, 2003), hlm. 9.

${ }^{39}$ Fadjar, A. Malik. School-Based Management. Penerjemah Noryamin Aini, dkk. (Jakarta: Logos, 2002), hlm. xv-xvi.

${ }^{40} \mathrm{lbid}, \mathrm{hlm}$. xvi.
} 
digunakan seluas-luasnya bagi peningkatan prestasi siswa dan mutu pendidikan pada umumnya. ${ }^{41}$

Pelaksanaan MBS secara efektif dan efisien menuntut seorang kepala sekolah yang memiliki pandangan luas tentang sekolah dan pendidikan. Wibawa kepala sekolah harus ditumbuhkembangkan dengan meningkatkan sikap kepedulian, semangat belajar, disiplin kerja, keteladanan dan hubungan manusiawi sebagai modal perwujudan iklim kerja yang kondusif. Kepala sekolah dituntut untuk melakukan fungsinya sebagai manajer sekolah dalam meningkatkan proses belajar mengajar, dengan melakukan supervisi kelas, membina, dan memberikan saran-saran positif kepada guru. Di samping itu, kepala sekolah juga harus melakukan tukar pikiran, sumbang saran, dan studi banding antarsekolah untuk menyerap kiat-kiat kepemimpinan dari kepala sekolah lain.

Pelaksanaan MBS juga menuntut guru untuk berkreasi dalam meningkatkan manajemen kelas. Guru adalah teladan dan panutan langsung peserta didik di kelas. Oleh karena itu, guru perlu siap dengan segala kewajiban, baik manajemen maupun persiapan isi materi pelajaran. Guru juga harus mengorganisasikan kelasnya dengan baik mulai jadwal pelajaran, pembagian tugas peserta didik, kebersihan dan ketertiban kelas, pengaturan tempat duduk peserta didik dan penempatan media pembelajaran pada tempatnya.

Pada sisi lain, pelaksanaan MBS yang ideal harus sesuai dengan karakteristik MBS dan harus melalui tahap-tahap pelaksanaan MBS. Perencanaan dan persiapan yang baik dalam pelaksanaan MBS akan membantu keberhasilan program tersebut. Hal itu akan menghasilkan mutu pendidikan yang semakin baik, ada kepedulian warga sekolah dan tanggung jawab sekolah pun akan semakin meningkat.

Dari beberapa hasil studi MBS Bank Dunia di beberapa negara diperoleh kesimpulan antara lain: (1) hasil studi di India, Papua Nugini, dan Chicago menunjukkan bahwa MBS dengan partisipasi masyarakatnya meningkatkan kehadiran siswa, dan (2) studi di Nikaragua menunjukkan bahwa telah terjadi peningkatan motivasi guru karena keterlibatannya dalam pengambilan keputusan di MBS. ${ }^{42}$ Selain itu, kehadiran guru dan siswa secara reguler meningkatkan perubahan positif terhadap pengalaman belajar para siswa. Menurut Fullan dan Watson, terdapat bukti yang nyata bahwa keterlibatan orang

\footnotetext{
${ }^{41}$ Sidi, Indra Djati. Menuju Masyarakat Belajar Menggagas Paradigma Baru Pendidikan. (Jakarta: Paramadina, 2001), hlm. 19-20.

${ }^{42}$ Nurkolis, Op.Cit., hlm. 251-256.
} 
tua dan masyarakat berpengaruh terhadap pembelajaran siswa, namun pada sekolahsekolah yang belum maju pengaruhnya masih terbatas. ${ }^{43}$

Sedangkan, hasil studi di Indonesia yang dilaksanakan oleh Subakir dan Sapari mengenai pelaksanaan MBS di Jawa Timur, ditemukan beberapa sumber daya masyarakat maupun pendidik. Namun demikian, secara umum pelaksanaan uji coba MBS di Jawa Timur berhasil dan sesuai dengan petunjuk yang telah ditetapkan. ${ }^{44}$ Manajemen sekolah khususnya manajemen keuangan pada umumnya sudah terbuka dan transparan walaupun partisipasi masyarakat masih beragam. Dalam pembelajaran terjadi perubahan yang cukup mendasar pada teknik dan metode pembelajaran.

Berangkat dari hasil-hasil penelitian yang cukup beragam tersebut, menimbulkan rasa ingin tahu peneliti tentang bagaimana pelaksanaan MBS di SMP Negeri 17 Purworejo. Sebagaimana telah diuraikan bahwa dari beberapa hasil studi mengenai MBS, terlihat pelaksanaan MBS yang masih beragam dan dari hasil observasi sementara peneliti di lapangan, hal tersebut dikarenakan permasalahan yang diidentifikasikan sebagai berikut ada kecenderungan kurangnya pengetahuan kepala sekolah, guru, orang tua murid, dan masyarakat tentang pelaksanaan MBS. Kurangnya pengetahuan tersebut mengakibatkan rendahnya partisipasi warga sekolah dan masyarakat dalam mendorong pelaksanaan MBS dalam praktek pengelolaan pendidikan di sekolah.

Berdasarkan latar belakang masalah yang berkaitan dengan berbagai persoalan yang melingkupi implementasi MBS, maka deskripsi faktual tentang kinerja kolektif penerapan MBS yang memberdayakan kepala sekolah, guru, siswa, pegawai TU, dan komite sekolah di SMP Negeri 17 Purworejo dalam konteks manajemen pendidikan merupakan fenomena yang sangat urgen untuk diungkap melalui penelitian. Di samping itu yang tidak kalah pentingnya adalah arah dari implementasi MBS untuk meningkatkan mutu pendidikan. Berdasarkan latar belakang di atas, penulis tertarik untuk mengangkatpermasalahan tersebut ke dalam sebuah penelitian dengan judul "Implementasi Manajemen Berbasis Sekolah untuk Meningkatkan Mutu Pendidikan di SMP N 17 Purworejo".

\section{KAJIAN LITERATUR}

\section{Manajemen Berbasis Sekolah}

\section{a. Pengertian MBS}

Menurut Mulyasa, manajemen berbasis sekolah merupakan suatu konsep yang menawarkan otonomi pada sekolah untuk menentukan kebijakan sekolah dalam rangka

\footnotetext{
${ }^{43} \mathrm{Ibid}, \mathrm{hlm} .256$.

${ }^{44}$ Ibid, hlm. 248-249.
} 
meningkatkan mutu, efisiensi dan pemerataan pendidikan agar dapat mengakomodasi keinginan masyarakat setempat serta menjalin kerjasama yang erat antara sekolah, masyarakat, dan pemerintah. ${ }^{45}$ Dalam konsep Mulyasa tersebut, terkandung informasi bahwa MBS penekanannya pada pemberian otonomi atau kewenangan yang luas kepada sekolah dalam mengelola pendidikan.

MBS mengacu pada manajemen sumber daya di tingkat sekolah dan bukan di suatu sistem atau tingkat yang sentralistik. Melalui MBS, sekolah diberi pengawasan lebih besar atas arah yang akan dicapai oleh organisasi sekolah tersebut. Dalam komponen kurikulum, misalnya, sekolah diberikan otonomi atas kurikulum yang dikembangkan. Di sini suatu kurikulum berbasis sekolah berarti bahwa masing-masing sekolah memutuskan bahan-bahan ajar apa akan digunakan, dan juga model pelaksanaan spesifik.

MBS merupakan bentuk alternatif sekolah dalam program desentralisasi bidang pendidikan, yang ditandai dengan otonomi luas di tingkat sekolah, partisipasi mayarakat yang tinggi tanpa mengabaikan kebijakan pendidikan nasional. Otonomi diberikan agar sekolah dapat leluasa mengelola sumberdaya sesuai dengan prioritas kebutuhan agar sekolah lebih tanggap terhadap kebutuhan setempat. Dalam hal ini, masyarakat juga dituntut lebih memahami pendidikan, membantu, serta mengontrol pengelolaan pendidikan. Sedangkan, kebijakan nasional yang menjadi prioritas pemerintah harus pula dilakukan oleh sekolah. Dengan demikian, dalam MBS, sekolah dituntut memilki accountability, baik di hadapan masyarakat maupun pemerintah. Manajemen berbasis sekolah bertujuan meningkatkan efisiensi, mutu dan pemerataan pendidikan. Peningkatan efisiensi diperoleh melalui keleluasaan mengelola sumberdaya, partisipasi masyarakat dan penyederhanaan birokrasi.

\section{b. Karakteristik MBS}

Manajemen berbasis sekolah memiliki karakteristik yang perlu dipahami oleh sekolah yang akan menerapkannya. Sekolah yang ingin berhasil dalam menerapkan manajemen berbasis sekolah harus memiliki karakteristik. Karakteritik manajemen berbasis sekolah bisa diketahui antara lain dari bagaimana sekolah dapat mengoptimalkan kinerja organisasi sekolah, proses kegiatan belajar mengajar, pengelolaan sumber daya manusia dan administrasinya.

c. Tahap-tahap MBS

\footnotetext{
45 Mulyasa, E. Manajemen Berbasis Sekolah, Konsep, Strategi, dan Implementasi. (Jakarta: Remaja Rosdakarya, 2002), hlm. 11.
} 
Tahap-tahap yang harus dilakukan dalam pelaksanaan manajemen berbasis sekolah adalah: (1) Melakukan Sosialisasi; (2) Mengidentifikasi Tantangan Nyata Sekolah; (3) Merumuskan Visi, Misi, Tujuan dan Sasaran Sekolah (Tujuan Situasional Sekolah); (4) Mengidentifikasi Fungsi-fungsi yang Diperlukan untuk Mencapai Sasaran; (5) Melakukan Analisis SWOT (Strength, Weakness, Opportunity, and Threat); (6) Menyusun Alternatif Langkah Pemecahan Persoalan; (7) Menyusun Rencana dan Program Peningkatan Mutu; (8) Melaksanakan Rencana Peningkatan Mutu; (9) Melakukan Evaluasi Pelaksanaan; dan (10) Merumuskan Sasaran Mutu.

Kesimpulan yang dperoleh dari uraian di atas adalah pelaksanaan manajemen berbasis sekolah harus melalui tahap-tahap yang urut dan berkesinambungan. Keberhasilan melalui tahap-tahap ini akan membantu pencapaian keberhasilan program.

\section{Manajemen berbasis sekolah yang menawarkan keleluasaan} pengelolaan sekolah memiliki potensi yang besar dalam menciptakan kepala sekolah, guru dan pengelola pendidikan yang profesional. Pelaksanaannya juga memerlukan seperangkat kewajiban, disertai dengan monitoring dan tuntutan pertanggung jawaban yang relatif tinggi, untuk menjamin bahwa sekolah selain memiliki otonomi juga memiliki kewajiban melaksanakan kebijakan pemerintah dan memenuhi harapan masyarakat sekolah. Sekolah juga dituntut mampu menampilkan pengelolaan sumber daya secara transparan, demokratis, tanpa monopoli, dan bertanggung jawab baik terhadap masyarakat maupun pemerintah dalam rangka meningkatkan kapasitas pelayanan terhadap peserta didik.

Kepala sekolah merupakan motor penggerak, penentu arah kebijakan sekolah yang akan menentukan bagaimana tujuan-tujuan sekolah dan pendidikan direalisasikan. Kepala sekolah juga dituntut untuk senantiasa meningkatkan efektivitas kinerja. Kinerja kepemimpinan kepala sekolah dalam kaitannya dengan manajemen berbasis sekolah adalah segala upaya yang dilakukan dan hasil yang dicapai oleh kepala sekolah dalam melaksanakan manajemen berbasis sekolah di sekolahnya tersebut.

\section{Mutu Pendidikan}

\section{a. Pengertian Mutu Pendidikan}

Mutu pendidikan dapat dilihat dalam dua hal, yakni mengacu pada proses pendidikan dan hasil pendidikan. Proses pendidikan yang bermutu apabila seluruh komponen pendidikan terlibat dalam proses pendidikan itu sendiri. Faktor-faktor dalam proses pendidikan adalah berbagai input, seperti bahan ajar, metodologi, sarana madrasah, dukungan administrasi dan sarana prasarana dan sumber daya lainnya serta penciptaan suasana kondusif. Sedangkan, mutu pendidikan dalam konteks hasil 
pendidikan mengacu pada prestasi yang dicapai oleh madrasah pada setiap kurun waktu tertentu.

Kualitas yang dimaksudkan dalam konteks pendidikan adalah kualitas dalam konsep relatif, terutama berhubungan dengan kepuasan pelanggan. Pelanggan pendidikan ada dua aspek, yaitu pelanggan internal dan eksternal.

Pendidikan dikatakan bermutu atau berkualitas apabila: (1) Pelanggan internal (kepala madrasah, guru dan karyawan madrasah) berkembang baik fisik maupun psikis. Secara fisik antara lain mendapatkan imbalan finansial. Sedangkan secara psikis adalah bila mereka diberi kesempatan untuk terus belajar dan mengembangkan kemampuan, bakat dan kreatifitasnya. (2) Pelanggan eksternal, dibedakan menjadi tiga, yaitu pelanggan Eksternal primer (para siswa) dan pelanggan eksternal sekunder (orang tua/wali, para pemimpin pemerintahan dan perusahan), dan pelanggan eksternal tersier (pasar kerja dan masyarakat luas).

Mutu pendidikan adalah pendidikan yang mampu menghasilkan kualitas pendidikan yang sesuai dengan tujuan pendidikan pada khususnya serta tujuan hidup pada umumnya. Peningkatan mutu pendidikan bukanlah upaya sederhana, melainkan suatu kegiatan dinamis dan penuh tantangan. Pendidikan selalu berubah seiring dengan perubahan jaman. Oleh karena itu pendidikan senantiasa memerlukan upaya perbaikan dan peningkatan mutu sejalan dengan semakin tingginya kebutuhan dan tuntunan kehidupan masyarakat.

\section{b. Ciri-ciri Mutu Pendidikan}

Era globaliasi merupakan era persaingan mutu. Oleh karena itu, lembaga pendidikan mulai dari tingkat tinggi harus memperhatikan mutupendidikan. Lembaga pendidikan berperan dalam kegiatan jasa pendidikanmaupun mengembangkan sumber daya manusia harus memilikikeunggulan-keunggulan yang diperioritaskan dalam lembaga pendidikantersebut.Transformasi menuju sekolah bermutu diawali dengan mengadopsidedikasi bersama terhadap mutu oleh dewan sekolah, administrator, staf,siswa, guru dan komunitas. Proses diawali dengan mengembangkan visidan misi mutu untuk wilayah dan setiap sekolah serta departemen dalam wilayah tersebut. ${ }^{46}$ Visi mutu difokuskanpada lima hal, yaitu: (1) Pemenuhan kebutuhan kostumer; (2) Keterlibatan total komunitas dalam program; (3) Pengukuran nilai tambah pendidikan; (4) Memandang Pendidikan sebagai suatu sistem; (5) Perbaikan berkelanjutan dengan selalu berupaya keras membuat outputpendidikan menjadi lebih baik.

\footnotetext{
${ }^{46}$ Arcaro, Jerome S. Pendidikan Berbasis Mutu: Prinsip-prinsip Perumusan dan Tata Langkah Penerapan, (Yogyakarta: Andi Offset, 2007), hlm. 85-89.
} 


\section{METODE PENELITIAN}

Pendekatan yang digunakan dalam penelitian ini adalah pendekatan deskriptif kualitatif yang bersifat eksploratif. Penelitian ini bertujuan untuk menghasilkan data yang dekriptif yang menggambarkan keadaan pelaksanaan manajemen berbasis sekolah. Setting dan lokasi penelitian ini berada di SMP Negeri 17 Purworejo Alasannya, karena SMP Negeri 17 Purworejo merupakan salah satu dari 43 SMP negeri yang menjadi pilot project penerapan SPMI, yaitu Standar Penjamin Mutu Internal di Kabupaten Purworejo. Lokasi ini penulis pilih sebagai obyek penelitian, karena penulis merasa tertarik dengan masalah penerapan SPMI, mendorong penulis ingin mengetahui/melihat bagaimana Imlementasi MBS (Manajemen Berbasis sekolah) untuk masa depan peningkatan mutu pendidikan. Adapun Waktu penelitian ini yaitu berlangsung antara 4 bulan, yaitu Juni sampai dengan Oktober 2019.

Subjek penelitian ini yaitu peneliti/penulis sendiri. Sedangkan responden penelitian ini yaitu orang-orang yang berhubungan dengan manajemen berbasis sekolah di SMP N 17 Purworejo, seperti: kepala sekolah, wakil kepala sekolah, guru, staf, dan siswa.

Teknik pengumpulan data merupakan cara yang digunakan peneliti untuk memperoleh data penelitian yang dibutuhkan. Proses pengumpulan data dalam penelitian ini dilakukan dengan: observasi, wawancara mendalam, dan dokumentasi.

Dalam menguji keabsahan data peneliti menggunakan tehnik Triangulasi, yakni teknik pemeriksaan keabsahan data yang memanfaatkan sesuatu yang lain diluar data untuk keperluan pengecekan atau sebagai pembanding terhadap data itu.Itu artinya melakukan validasi, dengan cara mengecek dokumen program dan bukti tertulis lainnya. ${ }^{47}$ Dalam penelitian ini menggunakan Triangulasi metode yaitu menggunakan dua strategi yaitu: (1) Pengecekan terhadap derajat kepercayaan penemuan hasil penelitian dengan beberapa tehnik pengumpulan data; (2) Pengecekan derajat kepercayaan beberapa sumber data dengan metode yang sama.

Langkah-langkah yang dilakukan penulis lakukan untuk menganalisis data yang sudah diperoleh dari hasil observasi, wawancara, dan dokumentasi yaitu dengan menggunakan model analisis data Miles dan Huberman sebagaimana yang dikutip oleh Sugiyono, yaitu reduksi data (data reduction), penyajian data (data display), dan penarikan kesimpulan (conclusion drawing/verification). ${ }^{48}$

\section{HASIL PENELITIAN DAN PEMBAHASAN}

\section{Otonomi Sekolah dalam Meningkatkan Mutu Pendidikan di SMP Negeri 17 Purworejo}

\footnotetext{
${ }^{47}$ Patton, Michael Quinn. Metode Evaluasi Kualitatif. (Yogyakarta: Pustaka Pelajar, 2006), hal. 280

${ }^{48}$ Sugiyono, Metode Penelitian Pendidikan, (Bandung: Alfabeta. 2009), hal. 254
} 
Mutu pendidikan merupakan hal yang penting bagi kemajuan bangsa. Mutu pendidikan senantiasa diupayakan bersama oleh sekolah. Peningkatan mutu pendidikan perlu disadari dan diupayakan bersama. Hal tersebut karena pendidikan adalah upaya berkelanjutan, yang membutuhkan waktu dan usaha keras. Diperlukan perbaikan berkelanjutan untuk itu.

Kompleksitas problem pendidikan harus diatasi dengan strategi yang tepat. Melalui MBS diharapkan sekolah akan mampu meningkatkan mutu pendidikan. Para personil sekolah harus memahami MBS secara baik. Mutu pendidikan itu merupakan persoalan mikro pendidikan yang terkait dengan persoalan kemampuan guru, kesiapan sekolah dalam mendukung proses belajar dengan menyediakan fasilitas yang diperlukan, dan partisipasi masyarakat pendukung pendidikan yang ada di wilayahnya disertai penataan manajemen.

Otonomi sekolah dalam meningkatkan mutu pendidikan di SMP Negeri 17 Purworejo merupakan manifestasi langkah esensial dari otonomi daerah. SMP Negeri 17 Purworejo menerapkan suatu terobosan kebijakan untuk otonomi pendidikan yang disebut manajemen berbasis sekolah (school based management). Melalui otonomi sekolah, SMP Negeri 17 Purworejo dapat lebih optimal dalam memerankan dan memenuhi kebutuhan nyata sekolah.

Sebagaimana dalam Depdiknas, bahwa "Pemerintah sekarang telah berkomitmen, bahwa pendidikan berkualitas hanya akan nyata terwujud, bila otonomi daerah berujung pada otonomi sekolah yang berbasiskan manajemen (School Based Management)". ${ }^{49}$ SMP Negeri 17 Purworejo telah menerapkan Manajemen Berbasis Sekolah (MBS) dalam upaya meningkatkan mutu pendidikan. Ini berarti telah mendukung pemerintah sebagaimana disampaikan.

Melalui MBS, SMP Negeri 17 Purworejo memiliki otonomi atau kemandirian dan mampu mengambil keputusan sendiri yang melibatkan secara langsung semua warga sekolah sesuai dengan standar pelayanan mutu yang ditetapkan oleh Pemerintah Pusat, Provinsi, Kabupaten, dan Kota.

Dalam bekerja, SMP Negeri 17 Purworejo memiliki prinsip efektif dan efisien. Oleh karena itu dalam pengambilan keputusan misalnya, sekolah melibatkan seluruh komponen sekolah serta pelibatan komite sekolah. Berdasarkan hasil penelitian yang penulis lakukan di lapangan, maka otonomi SMP Negeri 17 Purworejo dalam meningkatkan mutu pendidikan terlihat dari kebijakan-kebijakan yang ada. Sekolah menyusun dan menetapkan sendiri visi, misi, tujuan dan sasaran. Sekolah melakukan penerimaan siswa baru sesuai dengan kriteria yang ditentukan (daya tampung, kelayakan, dan proporsi guru : siswa). Sekolah mengadakan kegiatan-kegiatan yang menunjang peningkatan pengetahuan, sikap, dan keterampilan siswa. Sekolah mengupayakan fasilitas belajar yang memadai. Personil sekolah secara bersama-sama berkomitmen terhadap mutu. Mereka bekerja sebagai teamwork yang kompak.

\section{Partisipasi Sekolah dalam Meningkatkan Mutu Pendidikan di SMP Negeri 17}

\section{Purworejo}

Partisipasi sekolah dalam meningkatkan mutu pendidikan di SMP Negeri 17 Purworejo dilakukan dengan menjaslin kerjasama dengan berbagai pihak atau stakeholder terkait. Sekolah menjalin kerjasama dengan masyarakat dalam kerangka Manajemen Berbasis Sekolah. Sekolah memberikan kesempatan masyarakat dalam memberikan masukan bagi pertimbangan pengambilan keputusan sekolah.

SMP Negeri 17 Purworejo memberikan layanan pendidikan yang bermutu bagi masyarakat sesuai dengan konteks yang ada. Partisipasi sekolah dalam meningkatkan mutu pendidikan di SMP Negeri 17 Purworejo dilakukan dengan melibatkan stakeholder

\footnotetext{
49 Depdiknas. Manajemen Pendidikan Berbasis Sekolah Buku I Konsep dan Pelaksanaan, (Jakarta: Depdiknas, 2002).
} 
terkait. Mereka diikutsertakan dalam merencanakan dan menetapkan kebijakan sekolah. Peran serta aktif atau partisipasi tersebut diperlukan guna membantu penyelanggaraan pendidikan. Melalui pemberian ruang gerak yang cukup, diharapkan sekolah akan muncul kreativitas, inovasi, tanggung jawab, dan upaya yang sungguh-sungguh untuk mengembangkan sekolah.

SMP Negeri 17 Purworejo menerapkan Manajemen Berbasis Sekolah dalam usaha pencapaian mutu pendidikan. Hal tersebut terbukti dari sekolah yang memberi ruang gerak cukup dalam menjabarkan kurikulum. Menurut penulis, SMP Negeri 17 Purworejo akan memiliki peluang untuk menjadi "sekolah unggul", sesuai dengan potensi yang dimiliki. Apalagi jika sekolah bersedia mengikutsertakan masyarakat (stakeholder) terkait dalam pengambilan keputusan.

SMP Negeri 17 Purworejo memiliki program-program unggulan yang strategis. Ini tentu akan membawa pencapaian mutu pendidikan. Manajemen partisipatif yang telah dilakukan juga akan mendorong peran serta masyarakat lebih besar terhadap sekolah. Dengan usaha yang dilakukan oleh Dewan sekolah (komite sekolah) dalam memberikan pertimbangan-pertimbangan pada kebijakan-kebijakan akan membawa dampak positif juga.

SMP Negeri 17 Purworejo menentukan kebijakan sekolah berdasar pada konteks yang ada (mengacu kepada ketentuan nasional dan daerah), kemudian menetapkan visi dan misi sekolah dengan, menganalisis kebijakan pendidikan, melakukan komunikasi dengan pemerintah pusat, menyatukan seluruh komponen sekolah. Sekolah terus membangun kemitraan dengan lembaga lain yang akan membantu dalam peningkatan kualitas diri sekolah.

\section{Kepemimpinan Sekolah dalam Meningkatkan Mutu Pendidikan di SMP Negeri 17}

\section{Purworejo}

Kepala sekolah memiliki peran penting guna kemajuan sekolah. Tidak ada kepala sekolah yang baik tanpa kepala sekolah yang baik pula. Sebagai pemimpin pada satuan pendidikan, kepala sekolah bertanggung jawab terhadap keberhasilan pendidikan. Kepala sekolah harus bekerja dengan dilandasi kompetensi yang memadai. Tidak sembarangan orang menjadi kepala sekolah. Kepala sekolah yang baik akan mampu membawa sekolahnya pada peningkatan mutu pendidikan.

Kepala sekolah di SMP Negeri 17 Purworejo melaksanakan tugas berdasar pada tugas pokok dan fungsinya sebagai pemimpin di satuan pendidikan. Kepala sekolah memiliki dan melaksanakan kompetensinya. Kendatipun belum benar-benar optimal, 
namun ia terus melakukan perbaikan berkelanjutan. Kepala sekolah terus melakukan pembenahan sekolahnya guna peningkatan mutu.

Kepala sekolah di SMP Negeri 17 Purworejo tidak berpuas diri dengan yang sudah dimiliki. Beliau terus memperbaiki fasilitas dan proses pembelajaran yang sudah ada. Kepala sekolah juga menjalankan tugas dalam membina hubungan baik dengan semua personel sekolah. Kepala sekolah menerapkan fungsi-fungsi manajemen dalam aktivitas kerjanya, meliputi proses menggerakkan, mempengaruhi, memberikan motivasi dan mengarahkan orang-orang di dalam organisasi/lembaga pendidikan terutama untuk mencapai tujuan yang telah ditetapkan.

Kepala sekolah di SMP Negeri 17 Purworejo mampu menyeimbangkan peran sebagai leader dan manajer secara baik. Peran kepala sekolah sebagai manajer dalam meningkatkan mutu pendidikan di SMP Negeri 17 Purworejo tidak hanya memfokuskan pada pengelolaan peserta didik saja, namun kepada seluruh pihak yang terlibat dalam kegiatan pendidikan di sekolah seperti tenaga pendidik, peserta didik, staf dan komite sekolah juga dikelola dengan sebaik-baiknya bahkan pendataan mengenai sarana prasarana sekolah pun sangat diperhatikan. Kepala sekolah mampu bekerja dengan orang dan bukan orang. Artinya, kepala sekolah tidak hanya berfokus pada menjalin hubungan yang baik dengan para personil sekolah, namun ia mampu mengelola administrasi, fasilitas sekolah, ataupun sumber daya keuangan, dan sumber daya sekolah lainnya.

Dalam menjalankan tugasnya sebagai manajer, kepala sekolah SMP Negeri 17 Purworejo memperhatikan kualitas pembelajaran. Kepala sekolah memfasilitasi kelancaran pembelajaran. Untuk meningkatkan kualitas guru, kepala sekolah memberikan kesempatan kepada para guru untuk mengembangkan potensi mereka, seperti mengirim guru untuk melakukan pelatihan, seminar, dan sebagainya.

Peran Kepala Sekolah sebagai leader juga terlihat dari pelaksanaan kepemimpinan pendidikan. Kepala sekolah memiliki keterampilan konseptual, manusiawi, dan teknis. Kepala sekolah melakukan perencanaan, pengorganisasian, pengawasan, dan evaluasi bagi kemajuan sekolah.

\section{Kerja Tim Sekolah dalam Meningkatkan Mutu Pendidikan di SMP Negeri 17 Purworejo}

Kerja tim sangat penting bagi kemajuan pendidikan. Kerja tim yang kompak akan memberikan kontribusi bagi kelancaran dan kemudahan proses pembelajaran. Kerja tim 
merupakan usaha bersama yang akan membawa hasil optimal. Kerja tim yang saling bersinergi akan menghasilkan kinerja lebih tinggi daripada jumlah masukan individual.

Kerja tim di SMP Negeri 17 Purworejo dilakukan secara kompak. Mereka menjunjung tinggi asas kekeluargaan dan kebersamaan yang harmonis. Mereka bekerja sama satu sama lain sebagai satu kesatuan atau sinergi yang akan membantu meringankan pekerjaan. Kerja tim tersebut tentu akan menghasilkan energi positif.

Kerja tim di SMP Negeri 17 Purworejo terkoordinasi dengan baik. Kepala sekolah sebagai pemimpin satuan pendidikan mampu mengontrol kinerja mereka sebagai tim sukses yang kompak atau searah visi misi tujuan dan sasaran serta strategi sekolah. Usahausaha individual mereka merupakan manifestasi dari pelaksanaan tugas pokok dan fungsi kerja mereka.

Kontribusi per individu yang sangat baik dari para personil sekolah di SMP Negeri 17 Purworejo mampu menghasilkan kinerja yang lebih besar bagi kemajuan sekolah. Sinergi antar personil sekolah terbukti dari hasil kerja yang optimal. Sebagai satu kesatuan kerja, mereka mampu membawa sekolah pada pencapaian hasil kerja yang memuaskan. Kerja tim organisasi sekolah di SMP Negeri 17 Purworejo dapat dikatakan kompak dan searah dengan pencapaian visi miti tujuan dan sasaran (VMTS) sekolah.

Kerja tim di SMP Negeri 17 Purworejo didukung oleh kompetensi para personil atau SDM yang baik. Mereka memiliki Sense of Belonging and Sense of Responsibility terhadap sekolahnya. Mereka bekerja dengan berorientasi pada mutu pembelajaran. Kepala sekolah sebagai pemimpin juga mampu memanfaatkan segenap sumber daya yang dimiliki (yang meliputi: man, money, material, machine, methode, minute, market) secara baik. Supervisi juga dilakukan guna membantu kinerja guru, mengawasi, mengevaluasi, dan meningkatkan mutu PBM.

\section{KESIMPULAN}

Berdasarkan analisis data dan pembahasan yang diperoleh dalam penelitian ini, maka dapat diambil kesimpulan sebagai berikut:

1. Otonomi sekolah dalam meningkatkan mutu pendidikan di SMP Negeri 17 Purworejo sudah berjalan sesuai dengan ketentuan peraturan yang berlaku. Sekolah menyusun dan menetapkan visi, misi, strategi, tujuan, dan sasaran, serta tata tertib proses pembelajaran.

2. Partisipasi sekolah dalam meningkatkan mutu pendidikan di SMP Negeri 17 Purworejo dilakukan dengan melibatkan stakeholder terkait. Mereka diikutsertakan dalam merencanakan dan menetapkan kebijakan sekolah. Peran serta aktif atau partisipasi tersebut diperlukan guna membantu penyelanggaraan pendidikan. 
3. Kepemimpinan kepala sekolah dalam meningkatkan mutu pendidikan di SMP Negeri 17 Purworejo sudah baik. Kepala sekolah melaksanakan perannya sebagai pemimpin yang efektif. Kepala sekolah mampu menyeimbangkan peran sebagai leader dan manajer. Kepala sekolah mampu menggerakkan seluruh sumber daya yang dimilikinya serta mengoptimalkannya.

4. Kerja tim sekolah dalam meningkatkan mutu pendidikan di SMP Negeri 17 Purworejo yaitu dilakukan secara kompak dan menjunjung tinggi asas kekeluargaan serta kebersamaan. Sebagai sebuah tim kerja, mereka melaksanakan tugas sesuai tugas pokok dan fungsinya.

\section{DAFTAR PUSTAKA}

Arcaro, Jerome S. (2007) Pendidikan Berbasis Mutu: Prinsip-prinsip Perumusan dan Tata Langkah Penerapan, Yogyakarta: Andi Offset.

Depdiknas. (2002) Manajemen Pendidikan Berbasis Sekolah Buku I Konsep dan Pelaksanaan, Jakarta: Depdiknas.

Fadjar, A. Malik. (2002). School-Based Management. Penerjemah Noryamin Aini, dkk. Jakarta: Logos.

Mulyasa, E. (2002). Manajemen Berbasis Sekolah, Konsep, Strategi, dan Implementasi. Jakarta: Remaja Rosdakarya.

Nurkolis. (2003). Manajemen Berbasis Sekolah: Teori, Model, dan Aplikasi. Jakarta: Grasindo.

Patton, Michael Quinn. (2006). Metode Evaluasi Kualitatif. Yogyakarta: Pustaka Pelajar.

Sidi, Indra Djati. (2001). Menuju Masyarakat Belajar Menggagas Paradigma Baru Pendidikan). Jakarta: Paramadina.

Sugiyono. (2009). Metode Penelitian Pendidikan. Bandung: Alfabeta. 